Nicholas Augustinos*

nicholas.augustinos@nd.edu.au

The University of Notre Dame Australia

School of Law, Sydney

104 Broadway (P0 Box 944)

Broadway NSW 2007

\title{
The Role of Non-State Actors in the Cultural Heritage Field - The Case of the Orthodox Church and Its Heritage in Turkey
}

\begin{abstract}
The involvement of non-state actors in legal regimes concerning the protection of cultural heritage has been identified as a key challenge facing the development of international law in this field. This challenge is intensified when the relevant cultural heritage under consideration takes the form of religious sites whose use by a church community (non-state actor) for the purposes of its religious activities has been impacted upon by circumstances such as war or inter-ethnic conflict resulting in the displacement of that church community. This article contributes to this discussion by reference to a significant non-state actor in the field of religion and global affairs - the Orthodox Church - and specifically by reference to the Church's heritage in Turkey. After providing the reasons which justify a scholarly legal examination of the Church's assertion
\end{abstract}

\footnotetext{
* Nicholas Augustinos is a Senior Lecturer with the Sydney School of Law of The University of Notre Dame Australia. He is also a confirmed Ph.D. Candidate with the TC Beirne School of Law of the University of Queensland. His doctoral research concerns the heritage of the (Greek) Orthodox Church in Turkey, Cyprus, and Albania, and this article is the product of some of the doctoral research work he has conducted so far under the supervision of Professor Craig Forrest (as principal supervisor) and Dr. Lucas Lixinski (from the Faculty of Law of the University of NSW as associate supervisor). The work has also had the benefit of input from Dr. Alessandro Chechi (from the University of Geneva) and from Professor Anthony Cassimatis (from the TC Beirne School of Law). Nicholas is also involved in the work of the International Law Association's Committee on Participation in Global Cultural Heritage Governance as an Alternate Member (Australian Branch).
} 


\section{DEBUTS}

Nicholas Augustinos

of rights with respect to its heritage in Turkey, as well as an outline of the main measures which have been applied by Turkish authorities to this heritage, the article proceeds to offer a tentative overview and analysis of the relevant legal and policy framework and suggests certain issues requiring further scholarly exploration. It is argued that in addition to providing useful insights about the role of nonstate actors in the cultural heritage field, such further exploration can offer useful insights about a related topic which is currently relatively unexplored by cultural heritage commentators, namely, the post-conflict management of religious sites.

Keywords: cultural heritage law, religious heritage, non-state actors, Orthodox Church

\section{Introduction}

The ownership of, and access to, religious sites and religious artefacts has become an important area of concern for a number of stakeholders, including States, international organizations, and religious communities. Increasing attention is especially being given to how international law, and normative frameworks generally which regulate ownership of and access to religious sites and objects, are developing or might have further need to develop in order to properly deal with the nature of these places and objects as heritage, as well as with the various circumstances that might impact on that heritage such as war, inter-ethnic conflict (or potential inter-ethnic conflict), and the displacement of local populations. This topic has drawn the attention of academic commentators working through the lenses of cultural heritage law and/or religion and law (especially human rights law concerning freedom of religion). ${ }^{1}$

This article considers the place of the Orthodox Church within this topic/area of concern with respect to its religious heritage situated in Turkey. After setting the legal scene and outlining the relevant international law which potentially applies to matters concerning access to religious sites and recovery of religious artefacts, the article focuses on a significant non-state actor - the Orthodox Church - within the context of this legal discussion; with a view toward highlighting some of the legal understandings which underpin the Church's assertion of heritage rights in Turkey.

1 See for instance: S. Ferrari, A. Benzo (eds.), Between Cultural Diversity and Common Heritage: Legal and Religious Perspectives on the Sacred Places of the Mediterranean, Routledge, London 2016; G.M. Mose, The Destruction of Churches and Mosques in Bosnia-Herzegovina: Seeking a Rights-Based Approach to the Protection of Religious Cultural Property, "Buffalo Journal of International Law" 1997, Vol. 3; and R.P.B. Singh, The Contestation of Heritage: The Enduring Importance of Religion, in: B. Graham, P. Howard (eds.), The Ashgate Research Companion to Heritage and Identity, Ashgate, Farnham 2008. 
This article places the Orthodox Church within the context of this legal discussion by examining some of the measures that have been applied to its tangible heritage by Turkish authorities and the impact these measures have had on the ability of the Church to access, recover, or otherwise actively employ this tangible heritage for the purposes of its religious activities.

The aim of this examination is to provide a tentative overview and analysis of the relevant legal and policy framework. In particular, the article aims to firstly highlight some of the legal issues which these measures raise for the Orthodox Church and which the Church has encountered in its attempts to exercise its rights with respect to this heritage; secondly to show why further exploration of these legal issues is important; and thirdly to construct a clear, over-arching legal research question that brings together these measures with a view toward guiding further exploration in order to make an effective contribution to the current scholarly discussion concerning the normative regulation of religious heritage access and recovery.

In essence, the article argues that such further exploration is important not simply because it serves the Church's own heritage interests, but primarily because such an exploration can provide useful insights about a significant topic which is presently relatively unexplored by cultural heritage commentators; namely the role of non-state actors in the cultural heritage field. ${ }^{2}$

Actors with an interest in cultural heritage extend beyond just the nation-state (which can value heritage as national heritage). The involvement of such actors in legal regimes concerning the protection of cultural heritage has been identified as a key challenge facing the development of international law in this field. According to Blake:

[I]t can be stated that the actors with an interest in the protection and safeguarding of cultural heritage are many and hold diverse interests and objectives in this process that, at times, collide. It is therefore not an easy question to assign rights and concomitant duties with regard to cultural heritage under international law [...] the challenge facing international law in this field is to try to satisfy as many of the legitimate interests in heritage as possible while, at the same time, operating within a system primarily established by and for sovereign and equal States. ${ }^{3}$

\footnotetext{
2 Whilst there is a rich vein of literature on the general topic of non-state actors under international law (see for instance: A. Clapham, Human Rights Obligations of Non-State Actors, Oxford University Press, Oxford 2006; M. Noortmann, A. Reinisch, C. Ryngaert (eds.), Non-State Actors in International Law, Hart Publishing, Oxford 2015; C.M. Bailliet (ed.), Non-State Actors, Soft Law and Protective Regimes: From the Margins, Cambridge University Press, Cambridge 2012; B. Reinalda (ed.), The Ashgate Research Companion to Non-State Actors, Ashgate, Farnham 2011; J. D'Aspremont (ed.), Participants in the International Legal System, Routledge, London 2011; M. Noortmann, C. Ryngaert (eds.), Non-State Actor Dynamics in International Law. From Law-Takers to Law-Makers, Ashgate, Farnham 2010; and A. Bianchi (ed.), Non-State Actors and International Law, Ashgate, Farnham 2009); there has been limited commentary on the specific topic of the role of nonstate actors in the cultural heritage field (see for instance: A. Chechi, Non-State Actors and Cultural Heritage: Friends or Foes?, "Anuario de la Facultad de Derecho de la Universidad Autonoma de Madrid" 2015, Vol. 19).

3 J. Blake, International Cultural Heritage Law, Oxford University Press, Oxford 2015, pp. 21-22.
} 


\section{DEBUTS}

Nicholas Augustinos

This article specifically aims to further develop this discussion with reference to the Orthodox Church.

\section{Access to Religious Sites and Recovery of Religious Artefacts - Which Law Applies?}

The variety of circumstances affecting religious sites, as well as the nature of the artefacts located at those sites, are such that international cultural heritage law on its own is insufficient to deal with heritage claims concerning those sites and artefacts. These claims in fact generally raise issues under a multiplicity of laws; namely, cultural heritage law, human rights law, and minority law.

This point is well-made with respect to the legal protection of religious sites (and "sacred places" in particular) by Ferrari et al. in a book entitled Between Cultural Diversity and Common Heritage: Legal and Religious Perspectives on the Sacred Places of the Mediterranean. ${ }^{4}$ Ferrari suggests that certain general guidelines applying to all sacred places can be formulated, with relevant parties making modifications or adding further detailed provisions according to the particular needs of specific places. ${ }^{5}$ The general guidelines are published as an appendix to the book in the form of a declaration to be adopted on a non-binding "soft-law" basis by "states, international organizations, religious communities and other stakeholders".

Ferrari identifies the five guiding principles on which the declaration is based as follows: ${ }^{6}$ (i) the religious nature of sacred places and their link with religious freedom; (ii) the significance of the sacred places for the development of a plural society; (iii) the protection of sacred places; (iv) the relationship between sacred places and communities of the faithful; and ( $v$ ) access to sacred places. In fact Ferrari is critical of the ability of existing cultural heritage law to properly address sacred places. His criticism is essentially based on the lack of significance given to the right to religious freedom in the existing cultural heritage law normative framework. According to Ferrari: "an effective legal system cannot avoid recognizing the link between manifestations of religious faith and sacred places and looking at their protection through the lenses provided by the provisions that safeguard the individual and collective rights of religious freedom".?

Ferrari therefore proposes that sacred places be legally regulated by a protection system in which provisions safeguarding freedom of religion and belief, conventions protecting cultural heritage, and laws regarding minority and property rights converge. ${ }^{8}$

\footnotetext{
4 S. Ferrari, A. Benzo (eds.), op. cit.

5 Ibidem, p. 332.

6 Ibidem, pp. 333-334.

7 Ibidem, p. 10.

8 Ibidem, p. 332.
} 
The understanding that access to religious sites and the recovery of religious artefacts critically engages human rights provisions concerning freedom of religion is also supported by the analysis conducted by Mose. Mose in fact provides a good analysis of the human rights law underlying his argument in favour of the protection of locally-significant religious property (which may perhaps be nationally/internationally not very significant). ${ }^{9}$ It is based on human rights law concerning freedom of religion. ${ }^{10}$ In summary, without the protection of the physical buildings and instruments and materials by which one's religion can be manifested, there can be no freedom of religion. ${ }^{11}$ Where the relevant community asserting religious heritage rights constitutes a minority within a wider national population, minority rights will also be engaged. This is in addition to any underlying right to own and hold religious property, a right that might also be held by that community. As well as highlighting the interaction and complementarity between cultural heritage law and human rights law, these observations concerning access to religious heritage also raise certain questions which continue to be explored by academic commentators, or which require further exploration. These questions include: How have developments in human rights law influenced cultural heritage law?:12 How might developments in cultural heritage law perhaps influence human rights law?; and What is the relationship between the right to own and hold religious property and the human right to freedom of religion?

This article takes the view that an examination of certain heritage matters of concern to the Orthodox Church, and the Church's attempt to assert rights with respect to these matters, can cast some light on these questions. The following sections of this article therefore provide a brief introduction to the Orthodox Church and its heritage concerns, especially with respect to its heritage in Turkey.

\footnotetext{
9 G.M. Mose, op. cit., pp. 200-202.

10 Including the Universal Declaration of Human Rights, 10 December 1948, UNGA Res. 217 A(III), Article 18; International Covenant on Civil and Political Rights, 16 December 1966, 999 UNTS 171, Article 18; Declaration on the Elimination of All Forms of Intolerance and of Discrimination on Religion or Belief, 25 November 1981, A/RES/36/55.

11 See also L. Lixinski, Religious Cultural Heritage: The Law and Politics of Conservation, Iconoclasm and Identity, in: G. Hooper (ed.), Heritage at the Interface: Interpretation and Identity, University Press of Florida, Gainesville 2018, pp. 121-135.

12 For further analysis on this question, see A.F. Vrdoljak, Human Rights and Cultural Heritage in International Law, in: F. Lenzerini, A.F. Vrdoljak (eds.), International Law for Common Goods: Normative Perspectives on Human Rights, Culture and Nature, Hart Publishing, Oxford 2005, p. 139. Vrdoljak points out (at p. 171) that the main result of the influence which developments in human rights law have exercised over cultural heritage law is that States have been replaced by "communities, groups and individuals" as the primary holders of rights (and obligations). This article in fact considers whether the Orthodox Church might be one of the "groups" to benefit from the human rights developments which Vrdoljak identifies.
} 


\section{Placing the Orthodox Church within the Context of the Legal Discussion Concerning Access to Religious Sites and Recovery of Religious Artefacts, Especially with Respect to Its Heritage in Turkey}

\section{What is the Orthodox Church?}

The Orthodox Church is "a family of self-governing [Christian] Churches [...] held together, not by a centralized organization, not by a single prelate wielding absolute power over the whole body, but by the double bond of unity in the faith and communion in the sacraments". ${ }^{13}$ McGuckin estimates the number of Orthodox Christians worldwide at 210 million. They form a single communion, making them the second largest, single Christian denomination behind the Catholic Church. ${ }^{14}$ Although not exclusively a Greek Church (and most certainly not intended to be so), in Orthodoxy the primary cultural influence has been Greek, ${ }^{15}$ especially as extended historically through the Byzantine Empire and through the role played within Orthodoxy by the Ecumenical Patriarchate of Constantinople (Istanbul), which considers that it is very much the "Mother Church" of Orthodox Christian civilization. ${ }^{16}$ The significant influence exercised within the Orthodox world by the Ecumenical Patriarchate of Constantinople (Istanbul) (especially through the role and special position given to the Ecumenical Patriarch) cannot be reasonably denied. ${ }^{17}$ It is not the role of this article to provide a complete analysis of the rather complex legal personality of the Orthodox Church, which stems from the self-governing status of the churches which make up the Orthodox Church collective (or family) combined with the primacy of honour and special role which the collective concedes to the Ecumenical Patriarchate of Constantinople (Istanbul). For the purposes of this article, it is sufficiently accurate to conceive of the Orthodox Church as forming a group of multiple legal entities rather than a single legal

13 T. Ware, The Orthodox Church, rev. ed., Penguin Books, Harmondsworth 1985, p. 15.

14 J.A. McGuckin, The Orthodox Church: An Introduction to the History, Doctrine and Spiritual Culture, John Wiley \& Sons, Chichester 2009, p. 24.

15 T. Ware, op. cit., p. 12.

16 Refer to the Ecumenical Patriarchate's website: http://www.patriarchate.org [accessed: 3.05.2019].

17 According to T. Ware (op. cit., p. 15), "[t]he Patriarch of Constantinople is known as the 'Ecumenical' (or universal) Patriarch, and since the schism between east and west he has enjoyed a position of special honour among all the Orthodox communities; but he does not have the right to interfere in the internal affairs of other [Orthodox] Churches. His place resembles that of the Archbishop of Canterbury in the worldwide Anglican communion". The role of the Ecumenical Patriarch is also discussed by J.A. McGuckin (op. cit., p. 28). The recent granting of self-governing status (autocephaly) to Orthodox Christians in the Ukraine by the Ecumenical Patriarchate and the break in relations between the Moscow Patriarchate (Russian Orthodox (hurch) and the Ecumenical Patriarchate which followed have served to initiate intense de-

bate and contention within world of Orthodoxy about the role and position of the Ecumenical Patriarchate. 
entity. This is also suggested by those legal cases where the Church has attempted to assert rights with respect to its heritage. The names of those cases indicate that the entity with standing to assert rights is the specific self-governing church with an immediate and direct jurisdictional interest in the relevant heritage at stake, rather than the collective as a whole. ${ }^{18}$

Accordingly, this article focuses particularly on certain heritage claims of the Ecumenical Patriarchate of Constantinople (Istanbul), as it is the relevant self-governing Orthodox church with an immediate and direct jurisdictional interest in the Church's heritage in Turkey.

\section{Why examine the Church's claims with respect to its heritage in Turkey?}

The Ecumenical Patriarchate has successfully engaged "the law" as a significant stakeholder and human rights claimant. This is confirmed by the Buyukada Orphanage case initiated in the European Court of Human Rights (ECtHR), mention of which has already been made in footnote 18 . This case is discussed in more detail in the next section, together with the other cases that have been brought before the ECtHR with respect to the Orthodox heritage in Turkey, although not directly by the Ecumenical Patriarchate.

It is not only the abovementioned ECtHR litigation which makes the topic of the Orthodox heritage of Turkey a worthwhile area for further legal examination. A detailed opinion on the legal status of religious communities in Turkey and on the position of the Ecumenical Patriarchate has also been provided by the Venice Commission, offering further support to any such legal examination. ${ }^{19}$ There are also certain additional significant heritage matters of concern to the Church, which are discussed below and which are relevant to this examination.

An examination of the Church's assertion of rights with respect to its heritage in Turkey is therefore justified not only on the basis that it serves the Church's own heritage interests. More importantly, the cases and materials which accompany this assertion of heritage rights offer an interesting case study for research, whereby a contribution might be made to our understanding of international law, especially our understandings about non-state actors in the cultural heritage field and the position of such actors under international law. In addition, as will be shown below, such research might also make a contribution to our understandings about the relationship between cultural heritage law and human rights law, as well as the normative regulation of religious heritage access in a post-conflict context.

\footnotetext{
18 For instance, in the litigation which the Church initiated in the ECtHR with respect to the Turkish government's confiscation of the Church's "Greek Orphanage for Boys" in Buyukada, it was the Fener Rum Patrikliği (Ecumenical Patriarchy) v. Turkey which successfully prosecuted the claim (Application No. 14340/05, Judgment of 8 July 2008).
}

19 Below, note 29. 


\section{DEBUTS}

Nicholas Augustinos

\section{What measures have been applied to Orthodox heritage by authorities in Turkey?}

While this article does not mention all the various measures which have been applied by Turkish authorities to the Orthodox heritage under their control and in pursuit of purposes which are inconsistent with the ongoing use of that heritage by Orthodox Christians for religious purposes, some of the main measures are set out below.

It should be noted that these measures have been applied to Orthodox heritage following the displacement of a significant part of Turkey's local Greek population. ${ }^{20}$ They suggest the implementation of a strategy aimed essentially at undermining the viability of the continued presence of the Ecumenical Patriarchate in Turkey, as well as the confiscation of so-called "redundant" Orthodox religious and other sites previously used by the displaced Greek population. Certain Orthodox heritage sites in state hands have also been caught up in domestic political moves aimed at reviving Ottomanism and Islamicizing the Turkish Republic.

The first measure to be considered concerns the World Heritage listed Hagia Sophia in Istanbul, which began its existence as a Greek Orthodox church in 537 AD, but was converted into a mosque following the fall of Constantinople to the Ottomans in 1453. It was then converted into a museum by Kemal Ataturk in 1935. Despite its status as a museum, Turkey's Erdoğan government has recently made arrangements for the Koran to be read at Hagia Sophia and for a muezzin's call to prayer to be sung inside Hagia Sophia during the period of Ramadan. There are also proposals to turn Hagia Sophia back into a mosque. ${ }^{21}$ According to journalists, these proposals have been made in the context of an internal conflict within Turkey between secularists and Islamists, with the latter seeking the reconversion as part of the above-mentioned campaign to revive "Ottomanism" and to Islamicize the Turkish Republic. ${ }^{22}$

The second measure concerns the historic Greek Orthodox church of Hagia Sophia in Turkey's Trabzon province, which was converted into a mosque during Ottoman rule. In 1964 it was turned into a museum, but in 2013 it was re-converted back into a mosque. The Greek Orthodox churches of Hagia Sophia in Nicaea and Hagia Sophia in Eregli (Heraclea) have also undergone a similar process. Appar-

\footnotetext{
20 It is not the role of this article to provide a historical analysis of the circumstances surrounding this displacement, which mainly occurred following the conclusion of the Greco-Turkish War of 1919-1922, but also following certain events arising in Turkey in later years, especially in 1955.

21 L. Lixinski, op. cit., pp. 121-135.

22 O. Matthews, Islamists and Secularists Battle Over Turkey's Hagia Sophia Museum, "Newsweek", 2 June 2015, http://www.newsweek.com/2015/06/12/battle-over-hagia-sophia-338091.html [accessed: 3.05.2019]; M. Movesian, Will the Hagia Sophia Again Become a Mosque?, "First Things", 11 December 2013, https://www.firstthings.com/blogs/firstthoughts/2013/12/will-the-hagia-sophia-again-become-amosque [accessed: 3.05.2019]; Hagia Sophia - Church to Mosque...and Back?, "The Economist", 10 May 2014, https://www.economist.com/news/europe/21601895-talk-haghia-sophia-once-again-becoming-mosquechurch-mosqueand-back [accessed: 3.05.2019].
} 
ently, a further Hagia Sophia in ancient Adrianople dating to the 12th century is also to be renovated as a mosque (overturning earlier plans to restore it as a museum). According to a "Pravoslavie" report, nine "Hagia Sophia" churches in Turkey have been converted into mosques. There is also a proposal to convert the historic Greek Orthodox Monastery of Stoudios into a mosque. Part of the monastery complex had been converted into a mosque in the 15th century, but it fell into disrepair. After being gutted by two fires, it was abandoned in $1920 .^{23}$

A further measure concerns the permission - which Turkey's Erdoğan government had previously granted and later allowed to lapse - for the Orthodox Church to conduct a religious service at the World Heritage listed Panagia Soumela monastery in the Pontic Mountains of Turkey's Trabzon province on the feast day of the Dormition of the Theotokos (15 August), despite the monastery's ceasing of its operations in 1922 and its current status as a state-controlled major tourist attraction. Permission for this was initially given in 2010 and was renewed annually until 2015. The measure appears to have been taken as part of a push by Turkey's Culture Ministry to foster Turkey's Christian heritage as a means of attracting faith tourism. ${ }^{24}$ On 22 September 2015 the site was closed by Turkish authorities and permission has not been renewed, and the site has remained closed since that date until its very recent reopening. The reason given for the closure of the site was that it was in need of restoration. According to one report, this is merely a pretext to the implementation of a permanent ban on any future Orthodox religious services at the site. ${ }^{25}$ This matter awaits further clarification by Turkish authorities following the reopening of the site.

The measures concerning the Halki Theological School also warrant discussion. Halki has functioned as an Orthodox theological school in Turkey since 1844, but has not been permitted to operate as such since 1971. Prior to 1971 , legal authorization for the School's functioning was apparently based on a Turkish law which permitted the operation of private universities in Turkey. According to Emre Öktem, this law was held to be unconstitutional by Turkey's Constitutional

23 Erasing the Christian Past - A Fine Byzantine Church in Turkey has been Converted into a Mosque, "The Economist", 27 July 2013,http://www.economist.com/node/21582317/print [accessed:3.05.2019]; Ninth Hagia Sophia Church Converted into a Mosque in Turkey, "Pravoslavie", 25 September 2014, http://www.pravoslavie.ru/ english/73914.htm [accessed: 3.05.2019]; O. Matthews, op. cit.; C. Letsch, Turkey: Mystery Surrounds Decision to Turn Byzantine Church Museum into a Mosque, "EurasiaNet", 2 December 2011, http://www.eurasianet.org/ print/64627 [accessed: 3.05.2019]; A. Zaman, Another Byzantine Church Becomes Mosque in Turkey, "Al-Monitor", 7 August 2013, http://www.al-monitor.com/pulse/originals/2013/08/another-byzantine-church-becomes-a-mosque.html [accessed: 3.05.2019]; J. Resneck, Hagia Sophia Mosque? Turkish Leaders Call for Conversion of Istanbul Landmark, Alarming Religious Minorities, "Huffington Post", 4 December 2013, http:// www.huffingtonpost.com/2013/12/04/hagia-sophia-mosque_n_4386401.html [accessed: 3.05.2019].

24 S. Gusten, The Church that Politics Turned Into a Mosque, "The New York Times", 8 February 2012, http:// www.nytimes.com/2012/02/09/world/middleeast/the-church-that-politics-turned-into-a-mosque.html [accessed: 3.05 .2019$]$.

25 Pontian Outrage as Turkey Cancels August 15 Church Service at Panagia Soumela, "Greek City Times", 11 August 2016, https://greekcitytimes.com/2016/08/11/pontian-outrage-as-turkey-cancels-august-15church-service-at-panayia-soumela [accessed: 3.05 .2019$]$. 


\section{DEBUTS}

Nicholas Augustinos

Court and the School was forced to close. ${ }^{26}$ The Ecumenical Patriarchate seeks the reopening of the School, not only for the theological training of young priests of Turkey's Greek community, but also to train novices attending the School from throughout the Orthodox world. Given the historical significance of the School for the Ecumenical Patriarchate and world Orthodoxy, an alternative Turkish proposal whereby Orthodox Christian clergy would be trained in a department of Christian theology to be established within an existing faculty of theology at a public Turkish university has been rejected by the Ecumenical Patriarchate. ${ }^{27}$ Toktas and Aras provide another reason to explain why Turkey is resisting the opening of the Halki Theological School. Apparently the Turkish military and the National Security Council consider that the 2,500 strong surviving Greek Orthodox minority "constitutes a potential security threat to the territorial integrity of the Turkish state". ${ }^{28}$

An additional measure which must be noted concerns the Ecumenical Patriarchate's "Greek Orphanage for Boys" in Buyukada, which has been confiscated by the Turkish government. Action has been taken by the Ecumenical Patriarchate in the ECtHR with respect to the confiscation. The case has underscored the fact that the Ecumenical Patriarchate in Turkey does not have legal status under Turkish law and is consequently not permitted to exercise property rights over any Orthodox church in Turkey. ${ }^{29}$

Given the Ecumenical Patriarchate's lack of legal status under Turkish law, the question arises: How are property rights over Orthodox religious sites in Turkey (i.e. those which are not currently used as mosques) actually exercised? The sites fall into three categories. The first category includes all sites which are treated as state property (e.g. Hagia Sophia, Istanbul and Panagia Soumela, Trabzon). The second category encompasses those sites belonging to minority foundations regulated by the Directorate of Foundations. Under Turkish law, legal status is only afforded to those non-Muslim minorities which have been organized into foundations for the purposes of owning and operating a religious site, as well as minority schools, hospitals, and orphanages. ${ }^{30}$ In order to achieve legal personality, Turkey's Greek

26 E. Öktem, Turkey, in: G. Robbers, W.C. Durham (eds.), Encyclopedia of Law and Religion, BrillOnline Reference Works, 5 December 2017. However, according to Orthodoxwiki the School was closed following the enactment of a specific law in Turkey which prohibited the operation of private universities. The precise legal position behind the closure of the School requires further examination - it is unclear whether the School was closed as a matter of Turkish constitutional law (as suggested by Öktem) or whether it was closed as a result of the passage of a specific law by the Turkish parliament.

27 Ibidem.

28 S. Toktas, B. Aras, The EU and Minority Rights in Turkey, "Political Science Quarterly" 2010, Vol. 124(4).

29 Fener Rum Patrikliği (Ecumenical Patriarchy) v. Turkey; see also European Commission for Democracy Through Law (Venice Commission), Opinion on the Legal Status of Religious Communities in Turkey and the Right of the Orthodox Patriarchate of Istanbul to Use the Adjective "Ecumenical", Opinion No. 535/2009, Strasbourg, 15 March 2010, CDL-AD(2010)005 ("Venice Commission Opinion").

30 The operation of the foundation system for non-Muslim religious minorities in Turkey and the human rights implications of that system are discussed in the Venice Commission Opinion, p. [36]. 
Orthodox minority has organized itself into such foundations and certain of these foundations have taken action before the ECtHR with respect to property confiscations which have been carried out by the Turkish State pursuant to "subtle legal schemes". ${ }^{31}$ One such action concerned the confiscation of a Greek Orthodox educational facility in Fener, Istanbul, ${ }^{32}$ and another action concerned the confiscation of a Greek Orthodox religious site on the island of Tenedos (Bozcaada). ${ }^{33}$ In both instances the Court found violations of Article 1 of Protocol No. 1 of the European Convention of Human Rights (the right to property). ${ }^{34}$ According to Ktistakis, ${ }^{35}$ a further 13 Orthodox churches were confiscated during the 1970s and there are pending human rights cases by Greek Orthodox foundations before the ECtHR concerning these confiscations. ${ }^{36}$

Ktistakis ${ }^{37}$ points out that it is only those sites belonging to minority foundations which are covered by the religious freedom and other provisions of the international human rights covenants which Turkey has ratified (with some reservations). The problem is, however, that it is the Turkish State which unilaterally decides what is capable of being owned by minority foundations and what is not. This means that the Turkish State can determine through this mechanism which sites get the benefit of religious freedom protections under the international human rights law instruments it has ratified. ${ }^{38}$

31 E. Öktem, op. cit.

32 Fener Rum Erkek Lisesi Vakfi v. Turkey, Application No. 34478/97, Judgment of 9 January 2007.

33 Bozcaada Kimisis Teodoku Rum Ortodoks Kilisesi Vakfi v. Turkey, Application Nos 37639/03, 37655/03, 26736/04, and 42670/04, Judgment of 3 March 2009.

34 See E. Öktem, op. cit.

35 Y. Ktistakis, Turkey, paper presented at "Places of Worship and Holy Sites in Europe and the Middle East: Status and Protection under National and International Law" Conference, Cyprus, 8-10 November 2017.

36 The term "Greek Orthodox" rather than term "Orthodox" is occasionally used in this article to specifically indicate the use of Orthodox religious sites by Turkey's Greek minority community, especially under the foundation system for non-Muslim religious minorities discussed further below under the heading "Religious freedom and the Council of Europe's Venice Commission Opinion".

37 Y. Ktistakis, op. cit.

38 This observation raises the question about the effect of the reservations which Turkey has made to the human rights instruments it has ratified, e.g. that only those persons/entities which have legal personality under Turkish law are entitled to the benefit of Turkey's international human rights commitments. For instance, Article 1 of Protocol No. 1 of the ECHR (Right to Property) states that "every natural or legal person is entitled to the peaceful enjoyment of his possessions". The Church is not a natural person. Who defines who is a legal person? Does the operation of the Article presuppose that a legal person is to be defined under the national law of the State which ratifies the Convention? In Turkey the Ecumenical Patriarchate does not have legal personality. Thus the question arises: Are only those Greek Orthodox community bodies that have been established as "Foundations" and which have thereby acquired legal personality in Turkey entitled to the benefit of this right under the Convention? Ktistakis's comments would make sense if that is the case. But compare the wording of Article 9 of the ECHR, which states that "Everyone has the right" to freedom of thought, conscience, and religion. This wording suggests that the right applies to individuals who are natural persons. How does it extend to collective entities such as a church? Clearly this needs to be further explored. 


\section{DEBUTS}

Nicholas Augustinos

The third category of Orthodox religious sites in Turkey (which are not presently used as mosques) concerns those which have come into individual, private ownership. Given the Ecumenical Patriarchate's lack of legal status under Turkish law, in order to protect certain sites the bishops of the Ecumenical Patriarchate have had to personally acquire these sites in their own name (or arrange for their acquisition by a trusted third party individual).

\section{What Legal Issues Do These Measures Raise?}

\section{The characterization of the Ecumenical Patriarchate and the Orthodox community of Turkey as non-state actors}

The above-indicated measures affecting the Orthodox heritage in Turkey raise issues under human rights law, especially the right to freedom of religion (as provided in Article 9 of the European Convention of Human Rights [ECHR] ${ }^{39}$ and the related right of religious communities to possess property (Article 1 of Protocol No. 1 of the ECHR). ${ }^{40}$ As also shown above, the Ecumenical Patriarchate and the Greek Orthodox community foundations have had to engage with human rights law in order to defend their ownership of sites in Turkey. This action has particularly served to highlight the problems which arise as a result of the lack of legal status of the Ecumenical Patriarchate under Turkish law, as well as the lack of legal status of the Greek Orthodox community itself under Turkish law (apart from the foundation system). This situation clearly results in the legal characterization of both the Ecumenical Patriarchate and the community itself as "non-state actors" rather than as state or public law entities.

Whilst this characterization can raise important legal questions when a nonstate actor violates the rules of cultural heritage law (e.g. attribution, duty of the state to protect/prevent, etc.), in the context of the measures which have been applied by Turkish authorities to Orthodox heritage in Turkey, this characterization raises a separate set of legal questions; especially pertaining to the ability of such actors to engage international law to defend their ownership of and access to religious sites against actions taken by the State. Some of these legal questions are raised and considered in greater detail below.

39 Convention for the Protection of Human Rights and Fundamental Freedoms, 4 November 1950, ETS 5, as amended. 
How does a Church engage with human rights law? The Church as an entity exercising rights

In the Buyukada Orphanage case before the ECtHR, the Ecumenical Patriarchate successfully claimed a violation of Article 1 of Protocol No. 1 of the ECHR (the right to property) with respect to the confiscation of the orphanage by Turkish authorities. As mentioned above, ${ }^{41}$ this Article states that "every natural or legal person is entitled to the peaceful enjoyment of his possessions". Although the Ecumenical Patriarchate does not have legal status under Turkish law, it was able to demonstrate to the Court that it had purchased this property in Istanbul in 1902 and that, whilst allowing the orphanage to use the property, the Ecumenical Patriarchate still retained ownership. In 1935 however, the Turkish government gave formal recognition to the orphanage as owner of the property. The orphanage was apparently ordered by Turkish authorities to vacate the premises for safety reasons in 1964. The Turkish government then took over the management of the property in 1997 on the basis that the orphanage was "defunct". In 1999 the Turkish government arranged for the Ecumenical Patriarchate's title to be annulled, and that annulment of title was upheld by the Turkish courts. ${ }^{42}$

It is crucial to note that the Ecumenical Patriarchate's successful engagement with the ECHR in this case was based on the right to property. The decision of the ECtHR in that case does not appear to extend to any pronouncement on the question of whether there was also an accompanying violation of Article 9 of the ECHR concerning freedom of religion. As mentioned above, ${ }^{43}$ Article 9 provides that "Everyone has the right" to freedom of thought, conscience, and religion. This wording suggests that the right applies to individuals who are natural persons and the Ecumenical Patriarchate is clearly not a natural person. Thus the question arises: How could the Ecumenical Patriarchate be able to claim a violation of this human right with respect to its ability to access Orthodox heritage sites in Turkey and thereby become one of the "groups" to benefit from the human rights developments identified by Vrdoljak? ${ }^{44}$

This question clearly raises the issue of the link between individual rights and group rights, and in this instance how this might relate to the Church. Should the Church's rights as such derive/flow from individual human rights concerning freedom of religion?; or perhaps from individual human rights concerning cultural her-

\footnotetext{
41 Above, note 38.

42 The original 2008 decision of the ECtHR in this case is in French. An unofficial English translation of the Court's later "Just Satisfaction" judgment (15 June 2010) exists. The discussion of the background to the case is based on the European Centre For Law \& Justice case commentary: ECLJ Welcomes the ECHR Decision in the Christian Orphanage Case v. Turkey, https://eclj.org/eclj-welcomes-the-echr-decision-in-thechristian-orphanage-case-v-turkey [accessed: 8.04.2019].
}

43 Above, note 38.

44 Above, note 12. 


\section{DEBUTS}

Nicholas Augustinos

itage and identity? Or is a separate conceptualization required? In other words, is the Church to be regarded as a stand-alone entity asserting rights, or are its rights an extension of the individual/group rights of its members? When it comes to asserting rights, is the Church perhaps something more than a mere group?

Javier Martínez-Torrón's entry on the ECHR in the Encyclopedia of Law and Religion provides additional insight into the question of whether the Church should be regarded as a "group" or whether the Church has status as an entity beyond a mere group - a status which nevertheless reinforces its ability to assert a collective human right. ${ }^{45}$ According to Martínez-Torrón, although Article 9 of the ECHR is framed as an individual right, this does not preclude the extension of this right to churches. He suggests that churches in fact have a right to religious freedom and it would be "artificial" to differentiate between the religious freedom of a church and that of its adherents.

Martínez-Torrón makes a number of pertinent observations regarding the ability of churches to rely on Article 9 . He notes that "[a] religious group may actually act on behalf of its members and is consequently fully legitimated to claim a violation of Article $9 \mathrm{ECHR}$ ". ${ }^{6} \mathrm{He}$ also comments that:

Moreover, the ECtHR has declared that, as "religious communities traditionally and universally exist in the form of organised structures", this collective aspect of religious freedom is "indispensable for pluralism in a democratic society" and is connected with and reinforced by freedom of association, protected by Article $11 \mathrm{ECHR}{ }^{47}$

He further observes that:

However, it would be a mistake to consider churches or religious groups as mere associations. On the contrary, churches or belief groups are a specific type of organization, which are often essential for their members' exercise of religious freedom and require a high degree of internal autonomy, both organizational and functional. ${ }^{48}$

These observations are reinforced in the Council of Europe/ECtHR 2015 Guide on Article 9 of the European Convention on Human Rights: Freedom of Thought, Conscience and Religion. ${ }^{49}$ In Section 1.1 of the Guide (which concerns the impor-

\footnotetext{
45 See J. Martínez-Torrón, European Convention on Human Rights, in: G. Robbers (ed.), Encyclopedia of Law and Religion, BrillOnline Reference Works, 2015; especially his commentary under the subsection "Either Alone or in Community with Others".

46 Ibidem. Martínez-Torrón refers to the cases of ECtHR, Cha'are Shalom Ve Tsedek v. France, Application No. 27417/95, Judgment of 27 June 2000 and Metropolitan Church of Bessarabia v. Moldova, Application No. 45701/99, Judgment of 13 December 2001 in support of this observation.

47 J. Martínez-Torrón, op. cit. The author refers to the cases of Hasan and Chaush v. Bulgaria in support of this observation.

48 Ibidem.

49 Council of Europe/European Court of Human Rights, Guide on Article 9 of the European Convention on Human Rights: Freedom of Thought, Conscience and Religion, 2015.
} 
tance of Article 9 of the Convention in a democratic society and the locus standi of religious bodies) the following statement is made:

An ecclesiastical or religious body may, as such, exercise on behalf of its adherents the rights guaranteed by Article 9 of the Convention (Cha'are Shalom Ve Tsedek v. France [GC], s 72; Leela Forderkreis e.V. and Others v Germany, s 79). That means that a complaint lodged by a church or a religious organisation alleging a violation of the collective aspect of its adherents' freedom of religion is compatible ratione personae with the Convention, and the church or organisation may claim to be the "victim" of that violation within the meaning of Article 34 of the Convention. ${ }^{50}$

Although these points are made by Martínez-Torrón and supported in the Guide, the ECtHR did not make a determination on these points with respect to the Church in the Buyukada Orphanage case or in the other two ECtHR confiscation cases mentioned above concerning Orthodox heritage in Turkey. ${ }^{51}$ Instead, the judgments in both these cases focused on the violation of the right to property. It should be noted, however, that there have been other cases brought by the Orthodox Church before the ECtHR concerning its heritage in northern (occupied) Cyprus which have directly raised the question of a violation of Article 9 of the ECHR, and in which the Court did not extend to the Church the benefit of the arguments made by Martínez-Torrón and supported in the Guide. ${ }^{52}$ Thus I submit that uncertainty remains over the manner in which the Church as an entity is able to engage with the ECHR and exercise a collective human right to freedom of religion with a view to accessing or recovering heritage. This uncertainty is worthy of further academic exploration, as it is capable of providing useful insights about the role of non-state actors in the cultural heritage field, in particular with respect to their ability to engage with human rights law.

\section{The relationship between property rights and the right to freedom of religion}

Öktem is keen to point out that the ECtHR cases mentioned above concerning the Church's heritage in Turkey pertain to the right to property rather than to freedom of religion per se. He argues that "[a]lthough there are a considerable number of alleged violations of the ECHR by Turkey, cases concerned with the regulation of re-

50 Ibidem, p. 8 [11].

51 Above, notes 32 and 33 .

52 See Chrysostomos v. Turkey, Application No. 66611/09, Decision of inadmissibility of 4 January 2011 (an action initiated by the Archbishop of the Church of Cyprus in respect of the inability of the Church to freely access and recover its property in the occupied area); and Pavlides and Georgakis v. Turkey, Application Nos 9130/09 and 9143/09, Decision of inadmissibility of 2 July 2013 (an action initiated by a bishop of the Church of Cyprus and an individual in respect of interrupted access to the St Barnabas monastery in the occupied area). Surprisingly, no violations of religious freedom were found in these cases. A further examination of these cases is outside the scope of this article. 


\section{DEBUTS}

Nicholas Augustinos

ligious activity are quite recent and relatively rare, with few resulting in judgments against Turkey".$^{53}$ It is submitted that this view fails to give adequate consideration to the close association between the right to own and hold religious property and the right to freedom of religion. This close association is essentially based on the observation that there can be no freedom of religion without the enforcement of the ownership or custodial rights which secure access to the religious sites and artefacts by which one's religion is made manifest. This observation highlights the interaction and complementarity between human rights law and those aspects of cultural heritage law which treat cultural heritage (including religious heritage) as a form of property.

Religious freedom and the Council of Europe's Venice Commission Opinion on the Legal Status of Religious Communities in Turkey and the Right of the Orthodox Patriarchate of Istanbul to Use the Adjective "Ecumenical"

The Venice Commission Opinion footnotes a number of cases brought before the ECtHR concerning the violation of property rights of religious communities in Turkey. Of the cases footnoted, the cases of Fener Rum Erkek Lisesi Vakfi v. Turkey, Fener Rum Patrikliği (Ecumenical Patriarchy) v. Turkey and Bozcaada Kimisis Teodoku Rum Ortodoks Kilisesi Vakfi v. Turkey have already been referred to above. The other cases do not involve the Orthodox Church. ${ }^{54}$

The Opinion confirms that Article 9 of the ECHR (the fundamental right to freedom of thought, conscience, and religion) is related to the right of religious communities to possess property (and that this article is applied in conjunction with Article 1 of Protocol No. 1). ${ }^{55}$ Emre Öktem, however, refers to these ECtHR cases only as property right violations and not as religious rights infringements. ${ }^{56}$

The Opinion concludes that:

[...] on the basis of the case law of the ECtHR, there seems no doubt that the present Turkish system of not providing non-Muslim religious communities as such with the possibility to obtain legal personality amounts to an interference with the rights of these communities under Article 9 in conjunction with Article $11 \mathrm{ECHR} .{ }^{57}$

53 E. Öktem, op. cit.

54 Venice Commission Opinion, p. 4 [10].

55 Ibidem, p. 4[11].

56 E. Öktem, op. cit.

57 Venice Commission Opinion, p. 16 [58]. 
The refusal to grant legal personality can only be justified in exceptional circumstances. "The Venice Commission does not see any reason to assume that there are such exceptional circumstances" ${ }^{58}$ According to the Opinion:

The most problematic issue appears to be that religious communities have been losing properties that have historically belonged to them. One of the reasons for this is that under the foundation system the property is held by the foundation and not by the religious community itself, although in practice and from ancient times in reality it is clearly the property of the community (the church, rabbinate, etcetera). The problem is that in situations where the foundation falls away (the members died and the requirements for upholding the foundation are no longer met), the properties have been transferred to the state. This may be seen as confiscation, which is a matter under Article 1 of Protocol No. 1, and has been seen as an infringement by the ECtHR. ${ }^{59}$

Section 5 of the Opinion discusses the right of the Orthodox Patriarchate of Istanbul to use the title "ecumenical". Turkish authorities do not recognize the Patriarch as "ecumenical" (i.e. as leader of those Orthodox Christians throughout the world located in jurisdictions falling within the responsibility of the Ecumenical Patriarchate), and regard him only as leader of the Greek Orthodox minority based in Turkey. ${ }^{60}$ The Opinion refers to a 2007 judgment of Turkey's Court of Cassation which denied the Patriarch's ecumenical title. The Opinion makes clear that this is an internal ecclesiastical matter on which the Court was not competent to make an assessment and may have violated Article 9 of the ECHR in making its judgment. ${ }^{61}$

The Venice Commission Opinion expresses heavy criticism of the argument that denial of the ecumenical status of the Patriarch is somehow justified under the Treaty of Lausanne. ${ }^{62}$ In contrast, Öktem does not mention this in his entry on Turkey in the Encyclopedia of Law and Religion, where he comments that "the view of high-level members of government is that the use of the term 'ecumenical' in reference to the Patriarchate is in fact a clear violation of the Lausanne Treaty". ${ }^{63}$

Whilst the Venice Commission Opinion supports the reopening of the Halki seminary, it does not otherwise go into an examination of whether the continued closure of Halki breaches Article 9 and other European standards for freedom of belief. ${ }^{64}$ This "gap" requires further scholarly consideration. The Opinion does note, however, that the possibility of educating and employing clergy is a core element

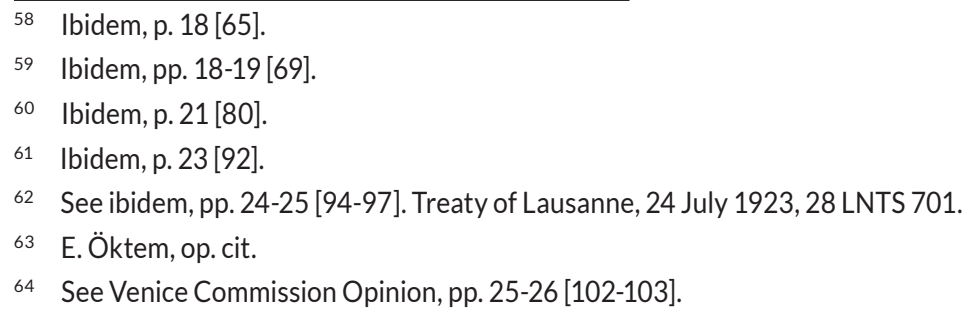




\section{DEBUTS}

Nicholas Augustinos

of freedom of religion, and that any obstruction of this by national authorities may amount to a violation of Article 9 of the ECHR, and also potentially of the right to education as protected by Article 2 of Protocol No. 1. ${ }^{65}$

There is, however, a Turkish counter-argument to this view, referred to by Öktem. Rather than allowing Halki to open, it appears that the Turkish authorities have come up with an alternative proposal in an attempt to deflect the point made by the Commission regarding violations of the ECHR. The Turkish authorities are suggesting that a department of Christian theology, within an existing faculty of theology, be established to train Christian clergy in Turkey (rather than re-opening Halki as a private university). According to Öktem, the Armenian patriarchate is eager to accept this, whilst the Ecumenical Patriarchate is hostile to the proposal and insists on the reopening of Halki.

This matter also requires further scholarly consideration. If Halki has historically been the place where Orthodox clergy novices from around the world have been educated and trained, is it acceptable in law for this historical institution with available facilities to be dismissed and remain closed in favour of an alternative proposal to establish a department of Christian theology within a Turkish faculty of theology?

It should be noted that the issue of the Halki seminary can be potentially linked to certain developments in Greece regarding the steps which have been taken for an Islamic theology department to be established within the faculty of Theology of the University of Thessaloniki. Should developments concerning Halki and the training of Orthodox Christian clerics in Turkey be tied to or depend upon these developments in Greece? Turkey's President Erdoğan has also apparently recently suggested that he might be prepared to consider the reopening of the Halki seminary in exchange for the opening of the Fethiye Mosque in Athens. ${ }^{66}$ Should the status of this seminary, which has great significance for world Orthodoxy and whose purpose is to educate and train Orthodox clergy novices from around the world, depend only upon bi-lateral relations between Greece and Turkey and the willingness of the Greek government to "exchange" the opening of a mosque in Athens for the reopening of the seminary (in addition to the new Greek government-funded mosque which is presently being constructed in Athens)? This matter too requires further consideration.

The final point to be made in this section is that the OSCE (Organization for Security and Co-operation in Europe) and Office for Democratic Institutions and Human Rights (ODIHR) published a set of guidelines in 2014 concerning the legal

\footnotetext{
65 Ibidem, p. 26 [104].

66 No Halki Seminary Without Minarets on Athens Mosque, Erdogan Says, "Ekathimerini", 18 February 2019 , http://www.ekathimerini.com/237805/article/ekathimerini/news/no-halki-seminary-without-minaretson-athens-mosque-erdogan-says [accessed: 3.05.2019].
} 
personality of religious and belief communities. ${ }^{67}$ There are a number of guidelines which, in the context of the Orthodox Church's experience in Turkey, would appear to have been breached. ${ }^{68}$ The Venice Commission Opinion discussed above is actually footnoted a number of times in support of the points made in these guidelines. The distinction the guidelines make between the community itself and its individual members should also be noted. This point is relevant to the comments made earlier as to whether the Church exercises rights as a stand-alone entity (i.e. as a community of believers), or whether those rights can only be exercised by its members individually. ${ }^{69}$

\section{Protection of cultural heritage in the event of armed conflict; displaced persons and the post-conflict management of religious sites}

The discussion so far of the legal issues raised by the measures that have been applied to Orthodox heritage by authorities in Turkey has essentially focused on human rights law considerations, especially considerations concerning freedom of religion in the context of access to the tangible structures and items by which one's religion can be made manifest.

However, in the context of which law is applicable (mentioned above in the section entitled "Access to Religious Sites and Recovery of Religious Artefacts - Which Law Applies?"), human rights law concerning freedom of religion is not the only relevant law. A multiplicity of laws are potentially relevant, including conventions protecting cultural heritage. The remaining discussion in this section will therefore consider some of the legal issues which arise when the measures are considered within the framework of the convergence of human rights law and cultural heritage law (especially the Convention for the Protection of Cultural Property in the Event of Armed Conflict - the 1954 Hague Convention and its Protocols).

There has been considerable discussion on the existing normative legal framework for the protection of cultural heritage during wartime and on the prosecution of individuals responsible for breaches of the framework. ${ }^{70}$ These commentaries

\footnotetext{
67 Venice Commission and Office for Democratic Institutions and Human Rights, Guidelines on the Legal Personality of Religious or Belief Communities, 2015.

68 See ibidem, pp. 15 [13], 16 [15], 21 [18], 21-22 [19-20].

69 Refer to discussion above under section entitled "How does a church engage with human rights law?".

70 See for instance, R. O'Keefe, The Protection of Cultural Property in Armed Conflict, Cambridge University Press, Cambridge 2006; C. Forrest, International Law and the Protection of Cultural Heritage, Routledge, London 2011, p. 78; P.J. Boylan, The Concept of Cultural Protection in Times of Armed Conflict: From the Crusades to the New Millennium, in: N. Brodie, K.W. Tubb (eds.), Illicit Antiquities, Routledge, London 2003, p. 43; T. Meron, The Protection of Cultural Property in the Event of Armed Conflict within the Case-law of the International Criminal Tribunal for the Former Yugoslavia, "Museum International" 2005, Vol. 57(4); H. Abtahi, The Protection of Cultural Property in Times of Armed Conflict: The Practices of the International Criminal Tribunal of the Former Yugoslavia, "Harvard Human Rights Journal" 2001, Vol. 14; K.J. Detling, Eternal Silence: The Destruction of Cultural Property in Yugoslavia, "Maryland Journal of International Law \& Trade" 1993, Vol. 17; and M. Lostal,
} 


\section{DEBUTS}

Nicholas Augustinos

confirm the extensive focus of the existing normative framework on necessary protections for cultural heritage during the course of war and/or armed conflict. Although there is some reference to actions which must be taken to protect cultural heritage from theft and pillaging, this refers mainly to the context of an existing armed conflict. The commentary also extends to a consideration of the obligations which arise under international law with respect to the occupation of any territory following an armed conflict.

The discourse on this topic with respect to the conflict in the former Yugoslavia raises some questions which are particularly relevant to the Church's experience in Turkey. Abtahi ${ }^{71}$ examines the destruction of cultural property during the Yugoslav war and gives extensive consideration to the prosecution of that destruction through the statute and case law of the International Criminal Tribunal for the former Yugoslavia (ICTY). He highlights certain key deficiencies in the ICTY's statute, in particular its failure to directly address the problem of restitution of illegally exported stolen cultural property or that which has been plundered and pillaged. $\mathrm{He}$ also notes some of the difficult questions which arise when the issue of restitution is considered in the context of the displacement of local populations, as took place in the Yugoslav conflict:

Article 24(3) of the Statute, as complemented by Rules 98 ter (B) and 105, provides for the return of property to its rightful owners. With regard to cultural property, this principle raises the question of who is the rightful owner of stolen cultural property: the state from where it was stolen, the municipality, or the village, in the case of those objects important only for the local inhabitants? Furthermore, what if individuals belonging to the ethnic majority of a state stole cultural property from a minority that no longer lives in the state because it was ethnically cleansed? In such a case, what entity can represent the displaced minority efficiently, or in other words, to whom should the restitution be addressed? ${ }^{72}$

These questions are relevant to the consideration of the Greek Orthodox heritage in Turkey, especially in light of the displacement of Turkey's local Greek population following the Greco-Turkish war of 1919-1922 and following certain events in 1955. The Panagia Soumela monastery, for instance, was actively used as a monastery up until its operations ceased in 1922 as a result of this displacement. Following Abtahi's lead (as noted above) one might therefore ask with respect to the Panagia Soumela site: Following the conclusion of the war, what entity can represent the displaced local community which used the site and to whom should restitution be addressed? Is it the Turkish State, or perhaps the community's Church (i.e. the Ecumenical Patriarchate which, despite the displacement, continues to

International Cultural Heritage Law in Armed Conflict: Case-Studies of Syria, Libya, Mali, the Invasion of Iraq, and the Buddhas of Bamiyan, Cambridge University Press, Cambridge 2017.

71 H. Abtahi, op. cit.

72 Ibidem, p. 29. 
maintain a presence in Turkey)? How might the heritage interests of the displaced community (or perhaps its descendants) be accommodated in any ongoing measures concerning the protection and management of the site? These are matters requiring further scholarly consideration.

Apart from Abtahi's commentary and questions (within the wider framework of the discussion on the protection of cultural heritage in the event of armed conflict as noted above), there does not appear to be much reference to or normative consideration as to what happens after the war is over with respect to the management of cultural sites located in the territory where the war was conducted, or with respect to claims for restitution following the war. O'Keefe for instance makes clear at the outset that his text does not deal with the topic of restitution of cultural property "illicitly removed during hostilities and belligerent occupation". He suggests that Articles 3 and 4 of the First Protocol to the 1954 Hague Convention are relevant to this topic, but does not examine them in depth. ${ }^{73}$ Detling, in her analysis of the application of international law to the destruction of cultural property during the early part of the Yugoslav war, also points out the limitations of that law, especially the failure of the 1954 Hague Convention to provide for restitution or adequate sanctions. ${ }^{74}$

Chechi ${ }^{75}$ provides some analysis on this issue with respect to Cyprus, especially in the context of the "confidence building measures" that have been adopted, post-conflict, for the island. The issue is a live one for the Church, and not only in Cyprus. As indicated in the section entitled "What measures have been applied to Orthodox heritage by authorities in Turkey?", the issue is also relevant to the Church's experience in Turkey, where the Erdoğan government has in the past allowed the Church some religious contact with certain heritage sites that had been taken over by the Turkish State (such as Panagia Soumela). An exploration of the legal context of such measures provides an opportunity for further scholarly consideration of how the normative considerations underlying the protection of cultural heritage in the event of armed conflict (i.e. during the course of war) are developing and/or might be in further need of development to address the regulation of access to religious sites after an armed conflict is over (i.e. to address the post-conflict management of religious sites).

As has already been mentioned above, the heritage interests of local communities that were displaced by war would be relevant to this discussion. As highlighted by the response to the discontinuation of the Dormition of the Theotokos

\footnotetext{
73 R. O'Keefe, op. cit., p. 3.

74 K.J. Detling, op. cit., p. 73.

75 A. Chechi, Beyond Protection: Cooperation as a Tool to Cope with Unresolved Cultural Heritage Issues in Post-Conflict Cyprus, "American Society of International Law Cultural Heritage \& Arts Review" 2011, Vol. 2(1), p. 22.
} 


\section{DEBUTS}

Nicholas Augustinos

feast day service at Panagia Soumela, and as further confirmed by Hayden et al.., ${ }^{76}$ the need to maintain contact with their spiritual heritage in the lands from which they were displaced is particularly felt by those Greeks (and their descendants) who were refugees from Turkey or displaced following the end of the Greco-Turkish war of 1919-1922.

In her analysis of the heritage of indigenous peoples and diasporas, Blake raises some interesting questions concerning the "cultural rights" which displaced persons and refugees might claim with regard to the cultural heritage of their country of origin. ${ }^{77}$ These questions are of direct relevance to the issue of the post-conflict management of religious heritage sites. In examining whether normative frameworks should be extended to address the post-conflict protection and management of these religious sites, one interesting question which arises is whether normative frameworks should countenance the ongoing religious use of these sites by displaced communities, as well as the additional question of whether normative frameworks should focus only on "sacred places" or perhaps extend further in their coverage to common places of worship. Further exploration of the heritage matters of concern to the Orthodox Church would provide some useful insights in response to these questions.

\section{Post-conflict management of religious sites - maintenance of religious consciousness}

Apart from the interests of displaced persons, the general question of whether religious consciousness should be maintained at religious sites located in post-conflict zones would also be relevant to an examination of how normative considerations might need to be developed to properly address the post-conflict management of those religious sites.

In the section of this article entitled "What measures have been applied to Orthodox heritage by authorities in Turkey?" it was shown how the question of the connection between religious consciousness and the Orthodox churches previously converted into museums remains a live issue in Turkey. These are essentially contested religious sites to be managed in a post-conflict context; with the relevant conflicts having occurred in 1453 (Byzantium vs Ottomans) or in 1919-1922 (Greece vs Turkey).

76 R.M. Hayden, T. Tanyeri-Erdemir, A. Erdemir, The Iconostasis in the Republican Mosque: Transformed Religious Sites as Artefacts of Intersecting Religioscapes, "International Journal of Middle East Studies" 2014, Vol. 46(3).

77 J. Blake, op. cit., pp. 282-283. See also C.E. Orser Jr., Transnational Diaspora and Rights of Heritage, in: H. Silverman, D.F. Ruggles (eds.), Cultural Heritage and Human Rights, Springer-Verlag, New York 2007, p. 92. 
Rana P.B. Singh ${ }^{78}$ examines a number of case studies to illustrate the role of religion in the "contestation of heritage". He refers to the Holy Land, religious sites in Southern Asia, Holy Cities in India, as well as to other areas such as Bosnia and Herzegovina. He documents how different religions can make rival claims to important religious sites. He also points out that these rival claims may lead to inter-community violence. ${ }^{79}$

Despite these contestations, Singh argues for an on-going and continuing connection between religious rites and these sites, because otherwise "even the best-preserved temple will be merely an empty shell and of little significance to local people". ${ }^{80}$ In other words, the preservation of these sites should not be devoid of that religious consciousness which is relevant to these sites and to the faith communities that seek to utilise these sites for religious purposes. ${ }^{81}$

How then do we deal with contestation and conflict? The author suggests that "defining heritage territory under the strict control of heritage law will help avoid conflicts and contestation, together with active public participation". 82

Although Singh does not provide specifics on how heritage law might be developed to secure his desired outcomes, as noted above the Ferrari et al. declaration has attempted to fill this gap. The maintenance of religious consciousness and on-going spiritual contact between sacred places and faith communities lie at the core of the declaration. ${ }^{83}$ However, Lixinski argues that at least in the case of the Hagia Sophia church in Istanbul, its status as a museum should be maintained and should override attempts to re-convert the site to a mosque..$^{84}$

Once again, these matters relate to the issue of the post-conflict management of religious heritage sites and require further exploration. In particular, the argument that normative frameworks which regulate post-conflict religious sites should give consideration to the religious dimension of heritage and not just the preservation of its cultural significance through "museumification" ${ }^{85}$ requires careful examination.

\footnotetext{
78 R.P.B. Singh, op. cit., pp. 125, 128.

79 Ibidem, p. 136.

80 Ibidem, p. 137.

81 Ibidem.

82 Ibidem, p. 133.

83 Brief mention should also be made here of the related research which has been conducted on the topic of contested religious sites from a non-legal, sociological/anthropological perspective. See R.M. Hayden, Antagonistic Tolerance: Competitive Sharing of Religious Sites and Spaces, Routledge, London 2016, in which a sociological/anthropological paradigm is proposed for the analysis of contested religious sites and spaces. Rabia Harmanasah's Performing Social Forgetting in a Post-Conflict Landscape: The Case of Cyprus ([Ph.D. diss.], University of Pittsburgh 2014) examines religious sites in Cyprus, including Orthodox sites, in the context of this paradigm.
}

84 L. Lixinski, op. cit.

85 See R. Harmanasah, op. cit. 


\section{DEBUTS}

Nicholas Augustinos

\section{A suggested legal research question to guide further research}

As stated at the outset, one of the central aims of this article was to search for a single over-arching legal research question that would bring together the various measures affecting the Church's heritage in Turkey - one which is capable of guiding further scholarly exploration of the Orthodox Church's ability to exercise rights with respect to its heritage. In light of the analysis which has been conducted above, that question might be stated as follows: What understandings about international law - and in particular about the engagement of non-state actors with international law and the post-conflict normative regulation of religious heritage access and recovery - can be drawn from an examination of the Orthodox Church's assertion of rights with respect to its heritage?

\section{Conclusions - Why Further Exploration of This Legal Research Question is Important}

An examination of the place of the Church as a non-state actor/subject of international law lies at the heart of the legal issues underlying this research question. As mentioned in the introduction, existing scholarly commentary illustrates the importance of carrying out further research work on the ability of non-state actors to engage international law (which is effectively a state-driven system of international law), especially with respect to heritage concerns. ${ }^{86}$ Further exploration of the above-mentioned legal issues (and specifically the proposed legal research question) would fulfil this role. On this point it should be further noted that I am not aware of any detailed work being carried out on the ability of the Orthodox Church to engage the "convergence" of cultural heritage law, human rights law, and minority protection law with respect to its heritage claims. In particular, I am not aware of any detailed work being done on the legal treatment of the nature of heritage objects which have both a cultural and spiritual dimension, especially in the context of the Orthodox Church's experience. Further exploration of the above-mentioned legal issues will at the same time constitute a highly original response to the call for further research on non-state actors and their engagement with law.

A closer examination of the distinction between "sacred places" and "common places of worship", the post-conflict management of religious heritage sites, as well as the religious rights of displaced persons, would push the current scholarly discussion on the legal issues surrounding the important topics of the protection of cultural heritage in the event of armed conflict and the protection of sacred sites especially those involving contested religious spaces - into new territory not previously researched.

86 J. Blake, op. cit. 
Finally, it should be noted that the heritage of the Church is located in territories which have experienced war and inter-ethnic conflict or which are prone to experience such conflicts. In addition, the sacredness of the sites and objects involved invokes very deep feelings which could be stirred up to sow the seeds of further violent conflict. According to Vrdoljak, there is "an urgent need to examine the role of culture and cultural heritage in the implementation of relevant international norms and maximizing successful, sustainable peace agreements" ${ }^{87}$ Further exploration of the above-mentioned legal issues will serve that need.

\section{References}

Abtahi H., The Protection of Cultural Property in Times of Armed Conflict: The Practices of the International Criminal Tribunal of the Former Yugoslavia, "Harvard Human Rights Journal" 2001, Vol. 14.

Bailliet C.M. (ed.), Non-State Actors, Soft Law and Protective Regimes: From the Margins, Cambridge University Press, Cambridge 2012.

Bianchi A. (ed.), Non-State Actors and International Law, Ashgate, Farnham 2009.

Blake J., International Cultural Heritage Law, Oxford University Press, Oxford 2015.

Boylan P.J., The Concept of Cultural Protection in Times of Armed Conflict: From the Crusades to the New Millennium, in: N. Brodie, K.W. Tubb (eds.), Illicit Antiquities, Routledge, London 2003.

Chechi A., Beyond Protection: Cooperation as a Tool to Cope with Unresolved Cultural Heritage Issues in Post-Conflict Cyprus, "American Society of International Law Cultural Heritage \& Arts Review" 2011, Vol. 2(1).

Chechi A., Non-State Actors and Cultural Heritage: Friends or Foes?, "Anuario de la Facultad de Derecho de la Universidad Autonoma de Madrid" 2015, Vol. 19.

Clapham A., Human Rights Obligations of Non-State Actors, Oxford University Press, Oxford 2006.

Convention for the Protection of Cultural Property in the Event of Armed Conflict, 14 May 1954, 249 UNTS 240.

Convention for the Protection of Human Rights and Fundamental Freedoms, 4 November 1950, ETS 5, as amended.

Council of Europe/European Court of Human Rights, Guide on Article 9 of the European Convention on Human Rights: Freedom of Thought, Conscience and Religion, 2015.

D'Aspremont J. (ed.), Participants in the International Legal System, Routledge, London 2011.

Declaration on the Elimination of All Forms of Intolerance and of Discrimination on Religion or Belief, 25 November 1981, A/RES/36/55.

Detling K.J., Eternal Silence: The Destruction of Cultural Property in Yugoslavia, "Maryland Journal of International Law \& Trade" 1993, Vol. 17.

Ecumenical Patriarchate website, http://www.patriarchate.org [accessed: 3.05.2019].

87 A.F. Vrdoljak, Enforcement of Restitution of Cultural Heritage Through Peace Agreements, in: F. Francioni, J. Gordley (eds.), Enforcing International Cultural Heritage Law, Oxford University Press, Oxford 2013. 


\section{DEBUTS}

Nicholas Augustinos

Erasing the Christian Past - A Fine Byzantine Church in Turkey has been Converted into a Mosque, "The Economist", 27 July 2013, http://www.economist.com/node/21582317/print [accessed: 3.05.2019].

European Centre For Law \& Justice, ECLJ Welcomes the ECHR Decision in the Christian Orphanage Case v. Turkey, https://eclj.org/eclj-welcomes-the-echr-decision-in-the-christian-orphanage-case-v-turkey [accessed: 8.04.2019].

European Commission for Democracy Through Law (Venice Commission), Opinion on the Legal Status of Religious Communities in Turkey and the Right of the Orthodox Patriarchate of Istanbul to Use the Adjective "Ecumenical", Opinion No. 535/2009, Strasbourg, 15 March 2010, CDL-AD(2010)005.

European Court of Human Rights, Bozcaada Kimisis Teodoku Rum Ortodoks Kilisesi Vakfi v. Turkey, Application Nos 37639/03, 37655/03, 26736/04, and 42670/04, Judgment of 3 March 2009.

European Court of Human Rights, Cha'are Shalom Ve Tsedek v. France, Application No. 27417/95, Judgment of 27 June 2000.

European Court of Human Rights, Chrysostomos v. Turkey, Application No. 66611/09, Decision of inadmissibility of 4 January 2011.

European Court of Human Rights, Fener Rum Erkek Lisesi Vakfi v. Turkey, Application No. 34478/97, Judgment of 9 January 2007.

European Court of Human Rights, Fener Rum Patrikliği (Ecumenical Patriarchy) v. Turkey, Application No. 14340/05, Judgment of 8 July 2008.

European Court of Human Rights, Metropolitan Church of Bessarabia v. Moldova, Application No. 45701/99, Judgment of 13 December 2001.

European Court of Human Rights, Pavlides and Georgakis v. Turkey, Application Nos 9130/09 and 9143/09, Decision of inadmissibility of 2 July 2013.

Ferrari S., Benzo A. (eds.), Between Cultural Diversity and Common Heritage: Legal and Religious Perspectives on the Sacred Places of the Mediterranean, Routledge, London 2016.

Forrest C., International Law and the Protection of Cultural Heritage, Routledge, London 2011.

Gusten S., The Church that Politics Turned Into a Mosque, "The New York Times" , 8 February 2012, http://www.nytimes.com/2012/02/09/world/middleeast/the-church-that-politics-turned-into-a-mosque.html [accessed: 3.05.2019].

Hagia Sophia - Church to Mosque...and Back?, "The Economist", 10 May 2014, https://www. economist.com/news/europe/21601895-talk-haghia-sophia-once-again-becomingmosque-church-mosqueand-back [accessed: 3.05.2019].

Harmanasah R., Performing Social Forgetting in a Post-Conflict Landscape: The Case of Cyprus [Ph.D. diss.], University of Pittsburgh 2014.

Hayden R.M., Antagonistic Tolerance: Competitive Sharing of Religious Sites and Spaces, Routledge, London 2016.

Hayden R.M., Tanveri-Erdemir T., Erdemir A., The Iconostasis in the Republican Mosque: Transformed Religious Sites as Artefacts of Intersecting Religioscapes, "International Journal of Middle East Studies" 2014, Vol. 46(3).

International Covenant on Civil and Political Rights, 16 December 1966, 999 UNTS 171.

Ktistakis Y., Turkey, paper presented at "Places of Worship and Holy Sites in Europe and the Middle East: Status and Protection under National and International Law" Conference, Cyprus, 8-10 November 2017. 
Letsch C., Turkey: Mystery Surrounds Decision to Turn Byzantine Church Museum into a Mosque, "EurasiaNet", 2 December 2011, http://www.eurasianet.org/print/64627 [accessed: 3.05.2019].

Lixinski L., Religious Cultural Heritage: The Law and Politics of Conservation, Iconoclasm and Identity, in: G. Hooper (ed.), Heritage at the Interface: Interpretation and Identity, University Press of Florida, Gainesville 2018.

Lostal M., International Cultural Heritage Law in Armed Conflict: Case-Studies of Syria, Libya, Mali, the Invasion of Iraq, and the Buddhas of Bamiyan, Cambridge University Press, Cambridge 2017.

Matthews O., Islamists and Secularists Battle Over Turkey's Hagia Sophia Museum, "Newsweek", 2 June 2015, http://www.newsweek.com/2015/06/12/battle-over-hagia-sophia-338091.html [accessed: 3.05.2019].

McGuckin J.A., The Orthodox Church: An Introduction to the History, Doctrine and Spiritual Culture, John Wiley \& Sons, Chichester 2009.

Meron T., The Protection of Cultural Property in the Event of Armed Conflict within the Case-law of the International Criminal Tribunal for the Former Yugoslavia, "Museum International" 2005, Vol. 57(4).

Mose G.M., The Destruction of Churches and Mosques in Bosnia-Herzegovina: Seeking a RightsBased Approach to the Protection of Religious Cultural Property, "Buffalo Journal of International Law" 1997, Vol. 3.

Movesian M., Will the Hagia Sophia Again Become a Mosque?, "First Things", 11 December 2013, https://www.firstthings.com/blogs/firstthoughts/2013/12/will-the-hagia-sophia-again-become-a-mosque [accessed: 3.05.2019].

Ninth Hagia Sophia Church Converted into a Mosque in Turkey, "Pravoslavie", 25 September 2014, http://www.pravoslavie.ru/english/73914.htm [accessed: 3.05.2019].

No Halki Seminary Without Minarets on Athens Mosque, Erdogan Says, "Ekathimerini", 18 February 2019, http://www.ekathimerini.com/237805/article/ekathimerini/news/ no-halki-seminary-without-minarets-on-athens-mosque-erdogan-says [accessed: 3.05.2019].

Noortmann M., Reinisch A., Ryngaert C. (eds.), Non-State Actors in International Law, Hart Publishing, Oxford 2015.

Noortmann M., Ryngaert C. (eds.), Non-State Actor Dynamics in International Law. From Law-Takers to Law-Makers, Ashgate, Farnham 2010.

O'Keefe R., The Protection of Cultural Property in Armed Conflict, Cambridge University Press, Cambridge 2006.

Öktem E., Turkey, in: G. Robbers, W.C. Durham (eds.), Encyclopedia of Law and Religion, BrillOnline Reference Works, 5 December 2017.

Orser Jr C.E., Transnational Diaspora and Rights of Heritage in: H. Silverman, D.F. Ruggles (eds.), Cultural Heritage and Human Rights, Springer-Verlag, New York 2007.

Pontian Outrage as Turkey Cancels August 15 Church Service at Panagia Soumela, "Greek City Times", 11 August 2016, https://greekcitytimes.com/2016/08/11/pontian-outrage-as-turkey-cancels-august-15-church-service-at-panayia-soumela [accessed: 3.05.2019].

Protocol No. 1 to the Convention for the Protection of Human Rights and Fundamental Freedoms, 20 March 1952, ETS 9. 


\section{DEBUTS}

Nicholas Augustinos

Reinalda B. (ed.), The Ashgate Research Companion to Non-State Actors, Ashgate, Farnham 2011.

Resneck J., Hagia Sophia Mosque? Turkish Leaders Call for Conversion of Istanbul Landmark, Alarming Religious Minorities, "Huffington Post", 4 December 2013, http://www.huffingtonpost.com/2013/12/04/hagia-sophia-mosque_n_4386401.html [accessed: 3.05.2019].

Singh R.P.B., The Contestation of Heritage: The Enduring Importance of Religion, in: B. Graham, P. Howard (eds.), The Ashgate Research Companion to Heritage and Identity, Ashgate, Farnham 2008.

Toktas S., Aras B., The EU and Minority Rights in Turkey, "Political Science Quarterly" 2010, Vol. 124(4).

Martínez-Torrón J., European Convention on Human Rights, in: G. Robbers (ed.), Encyclopedia of Law and Religion, BrillOnline Reference Works, 2015.

Treaty of Lausanne, 24 July 1923, 28 LNTS 701.

Universal Declaration of Human Rights, 10 December 1948, UNGA Res. 217 A(III).

Venice Commission and Office for Democratic Institutions and Human Rights, Guidelines on the Legal Personality of Religious or Belief Communities, 2015.

Vrdoljak A.F., Enforcement of Restitution of Cultural Heritage Through Peace Agreements, in: F. Francioni, J. Gordley (eds.), Enforcing International Cultural Heritage Law, Oxford University Press, Oxford 2013.

Vrdoljak A.F., Human Rights and Cultural Heritage in International Law, in: F. Lenzerini, A.F. Vrdoljak (eds.), International Law for Common Goods: Normative Perspectives on Human Rights, Culture and Nature, Hart Publishing, Oxford 2005.

Ware T., The Orthodox Church, rev. ed., Penguin Books, Harmondsworth 1985.

Zaman A., Another Byzantine Church Becomes Mosque in Turkey, "Al-Monitor", 7 August 2013, http://www.al-monitor.com/pulse/originals/2013/08/another-byzantine-church-becomes-a-mosque.html [accessed: 3.05.2019]. 